\title{
ANALISIS KEMAMPUAN BERPIKIR KREATIF MATEMATIS SISWA SD NEGERI 40 AMBON PADA MATERI BANGUN DATAR
}

\author{
Rachmawati T ${ }^{1}$, Theresia Laurens ${ }^{2}$, La Moma $^{3}$ \\ 1,2,3Program Studi Magister Pendidikan Matematika, Pascasarjana, Universitas Pattimura \\ Jalan Ir. M. Putuhena, Kampus Unpatti, Poka, Ambon, Indonesia \\ e-mail:
}

\begin{abstract}
Abstrak
Tujuan penelitian ini adalah untuk mengetahui kemampuan berpikir kreatif matematis siswa kelas VI SD Negeri 40 Ambon pada materi bangun datar. Jenis penelitian ini adalah penelitian deskriptif dengan pendekatan kualitatif. Subjek dalam penelitian ini adalah siswa kelas VI SD Negeri 40 Ambon pada semester 2 tahun pelajaran 2018/2019 sebanyak lima orang. Teknik pengambilan subjek dilakukan dengan cara purposive sampling. Metode pengumpulan data melalui tes berpikir kreatif matematis dan wawancara. Teknik analisis data merujuk pada pendapat Miles dan L-Luberman yaitu tahap reduksi data, tahap penyajian data, dan tahap penarikan kesimpulan. Hasil penelitian menunjukkan bahwa kelima subjek yang mewakili tiap tingkat kemampuan berpikir kreatif memiliki karakter yang berbeda-beda dalam memperlihatkan indikator kemampuan berpikir kreatif
\end{abstract}

Kata Kunci: Analisis, Kemampuan Berpikir Kreatif Matematis

\section{ANALYSIS OF MATHEMATICAL CREATIVE THINGKING SKILLS OF STUDENTS AT SD NEGERI 40 AMBON ON FLAT MATERIAL}

\begin{abstract}
The purpose of this study was to determine the mathematical creative thinking ability of Grade VI students of SD Negeri 40 Ambon on flat material. This type of research is a descriptive study with a qualitative approach. The subjects in this study were fifth grade students of SD Negeri 40 Ambon in semester 2 of 2018/2019 academic year as many as five people. The subject taking technique is done by purposive sampling. Methods of data collection through tests of mathematical creative thinking and interviews. Data analysis techniques refer to the opinion of Miles and L-Luberman, namely the data reduction stage, the data presentation stage, and the conclusion drawing stage. The results showed that the five subjects representing each level of creative thinking ability had different characters in showing indicators of creative thinking ability
\end{abstract}

Keywords: Analysis, Mathematical Creative Thinking Ability

\section{Pendahuluan}

Tujuan pendidikan nasional menurut pasal 3 UU No 20 Sisdiknas Tahun 2003 adalah berkembangnya potensi peserta didik agar menjadi manusia yang beriman dan bertakwa kepada Tuhan Yang Maha Esa, berakhlak mulia, sehat, berilmu, cakap, kreatif, mandiri, dan menjadi warga negara yang demokratis serta bertanggung jawab. Sedangkan tujuan pendidikan pada kurikulum 2013 adalah untuk mempersiapkan manusia Indonesia agar memiliki kemampuan hidup sebagai pribadi dan warga negara yang beriman, produktif, kreatif, inovatif, dan efektif serta mampu berkontribusi pada kehidupan bermasyarakat, berbangsa, bernegara, dan peradaban dunia. Tampak pada dua tujuan pendidikan di atas, salah satu kemampuan yang ingin dicapai adalah kemampuan berpikir kreatif.

Beberapa penelitian di dunia pendidikan internasional menyebutkan bahwa kemampuan berpikir kreatif masih perlu dikembangkan. Hah menyatakan bahwa di Korea kemampuan berpikir kreatif pada umur remaja masih dikatakan sangat rendah. Padahal Korea merupakan satu di antara 
negara yang memiliki kemampuan matematika terbaik dalam beberapa studi internasional. Penelitian lain dilakukan oleh Turkmen yang menyatakan bahwa siswa di Turki hanya mencapai aspek keaslian dan kelancaran dalam menyelesaikan tes yang diberikan. Hal tersebut tak jauh berbeda dengan hasil penelitian di Indonesia. Dalam dekade terakhir Indonesia selalu menempati posisi bawah di beberapa studi internasional seperti PISA (Programme for International Student Assessment) dan TIMSS (Trends in International Mathematic and Science Study). Penelitian tersebut menunjukkan bahwa sebagian besar siswa baik di Indonesia maupun internasional kurang mampu untuk mengembangkan potensi berpikir kreatifnya (Amalia, dkk, 2018).

Kurangnya kemampuan berpikir kreatif juga ditunjukkan oleh beberapa penelitian sebelumnya yang mengukur kemampuan berpikir kreatif yang mendukung penelitian ini, seperti halnya penelitian yang dilakukan oleh Tri Mulyaningsih dan Novisita Ratu, (2018). Hasil penelitian menunjukkan bahwa 1 subjek mampu memperlihatkan tingkat kemampuan berpikir kreatif 4 atau sangat kreatif, 1 subjek mampu memperlihatkan tingkat kemampuan berpikir kreatif 3 atau kreatif dan 1 subjek memperlihatkan tingkat kemampuan berpikir kreatif 1 atau kurang kreatif. Hal ini menunjukkan bahwa terdapat perbedaan tingkat kemampuan berpikir kreatif matematis siswa dalam jenjang pendidikan yang sama. Penelitian relevan lainnya seperti yang dilakukan oleh Dini Ramadhani dan Nuryanis, (2017). Hasil penelitian menunjukkan bahwa dari 16 siswa pada kategori tinggi, 10 orang berada pada level TBKM level 3 (kreatif) dan 6 orang berada pada TBKM level 2 (cukup kreatif). Pada siswa kategori sedang yang berjumlah 16 siswa, terdapat 6 orang berada pada TBKM level 3 (kreatif) dan sebanyak 10 orang berada pada TBKM level 2 (cukup kreatif). Pada siswa kategori kurang dengan jumlah siswa sebanyak 16 orang, sebanyak 2 orang berada pada TBKM level 3 (kreatif), 7 orang berada pada TBKM level 2 (cukup kreatif), dan sebanyak 7 orang berada pada TBKM level 1 (kurang kreatif). Beberapa penelitian tersebut menunjukkan bahwa masih banyak siswa yang termasuk dalam kemampuan berpikir kreatif yang rendah sehingga menunjukkan masih banyak siswa yang termasuk dalam kemampuan berpikir kreatif yang rendah sehingga pengembangan hendaknya perlu dilakukan.

Mengembangkan kemampuan berpikir logis, analitis, sistematis, kritis maupun bekerjasama sudah lama menjadi fokus dan perhatian pendidikan matematika di sekolah, karena hal itu berkaitan dengan sifat dan karakteristik keilmuan matematika (Siswono, 2008), tetapi fokus dan perhatian pada upaya peningkatan kemampuan berpikir kreatif dalam pembelajaran matematika masih jarang dikembangkan. Kemampuan ini (berpikir kreatif) dalam konteks pembelajaran matematika adalah kemampuan yang merangsang siswa untuk menemukan solusi yang beragam dari kemampuan berpikir siswa.

Munandar (2012) mengatakan bahwa kemampuan berpikir kreatif perlu dikembangkan oleh peserta didik karena memiliki banyak manfaat, diantaranya yaitu berpikir kreatif dapat mewujudkan dirinya, karena perwujudan diri merupakan kebutuhan pokok dalam hidup manusia. Selain itu kemampuan berpikir kreatif juga memungkinkan peserta didik melihat bermacam-macam kemungkinan penyelesaian terhadap suatu masalah dalam matematika. Kemampuan berpikir disini diantaranya merupakan kemampuan menemukan jawaban yang paling tepat, mampu melihat suatu masalah dari berbagai sudut pandang dan mampu melahirkan banyak gagasan yang merupakan indikator kelancaran dan keluwesan.

Kemampuan berpikir kreatif dalam matematika yang kemudian dikenal kemampuan berpikir keatif matematis merupakan kemampuan yang perlu ada pada diri siswa untuk menganalisis permasalahan matematika dari berbagai sudut pandang kemudian menyelesaikannya dengan kemampuan banyak solusi dan serta melahirkan ide-ide kreatif dan banyak gagasan. Namun kenyataannya, kemampuan berpikir kreatif matematis yang merupakan salah satu tujuan pendidikan tersebut belum tercapai dengan maksimal. Salah satu penelitian Fardah (2012) yang menjelaskan bahwa kemampuan berpikir kreatif matematis siswa tingkat sekolah dasar dan menengah masih dalam kategori rendah, yaitu sebesar 46,67\%. Penelitian ini mengukur kemampuan berpikir kreatif menggunakan tes open-ended yang dirancang, sehingga dapat menggambarkan proses berpikir kreatif dengan lebih jelas.

Menurut Hendriana, dkk (2018), pada dasarnya, berpikir kreatif matematis merupakan kemampuan matematis esensial yang perlu dikuasai dan dikembangkan pada siswa yang belajar matematika. Beberapa rasional yang mendasari pernyataan tersebut diantaranya:

1. Berpikir kreatif matematis termuat dalam kurikulum dan tujuan pembelajaran matematika (KTSP, 2006, Kurikulum Matematika, 2013), dan 
sesuai dengan visi matematika antara lain: melatih berpikir yang logis, sistematis, kritis, kreatif, cermat, serta berpikir objektif dan terbuka untuk menghadapi masa depan yang selalu berubah.

2. Berpikir kreatif secara umum dan dalam matematika merupakan bagian keterampilan hidup yang sangat diperlukan siswa dalam menghadapi kemajuan IPTEK yang semakin pesat serta tantangan, tuntutan, dan persaingan global yang semakin ketat.

3. Individu yang diberi kesempatan berpikir kreatif akan tumbuh sehat dan mampu menghadapi tantangan. Sebaliknya, individu yang tidak diperkenankan berpikir kreatif akan menjadi frustasi dan tidak puas.

Kemampuan berpikir kreatif matematis
dalam menyelesaikan masalah dapat dikembangkan salah satunya pada geometri materi bangun datar. Hal ini sesuai dengan pendapat Siswono (2006) yang menyatakan bahwa materi segi empat atau segitiga dapat digunakan dalam mengidentifikasi kemampuan berpikir kreatif siswa karena memiliki banyak penyelesaian dan dapat mendorong kreativitas siswa.

Menurut Silver, mengukur berpikir kreatif adalah hal yang perlu dilakukan. Beberapa peneliti menggunakan tes berpikir kreatif seperti TTCT (Torrance Test of Creative Thinking), CAMT (Creative Ability in Mathematical Test), Guilford Alternative Uses Task dan alat ukur lainnya, sedangkan Getzel dan Jackson menggunakan tugas yang mempunyai banyak jawaban atau banyak cara penyelesaian (Fardah, 2012).

Silver menjelaskan bahwa penilaian kemampuan berpikir kreatif dalam pelajaran matematika (berpikir kreatif matematis) dilakukan dengan menggunakan The Torance Tests of Creative Thinking (TTCT). Tiga komponen kunci yang dinilai dalam menggunakan TTCT adalah kefasihan (fluency), fleksibilitas dan kebaruan (novelty). Kefasihan mengacu pada banyaknya ide-ide yang dibuat dalam merespon sebuah perintah. Fleksibilitas tampak pada perubahanperubahan pendekatan ketika merespon perintah. Kebaruan merupakan keaslian ide yang dibuat dalam merespon perintah (Ramadhani dan Nuryanis, 2017).

Menurut Siswono (2008), kefasihan mengacu pada kemampuan siswa memberikan jawaban yang beragam dan benar. Beberapa jawaban dikatakan beragam apabila jawaban- jawaban tampak berlainan dan mengikuti pola tertentu. Fleksibilitas mengacu pada kemampuan siswa menyelesaikan masalah dengan berbagai cara yang berbeda. Kebaruan mengacu pada kemampuan siswa menjawab masalah dengan beberapa jawaban yang berbeda-beda namun bernilai benar atau satu jawaban yang "tidak biasa" dilakukan oleh siswa pada tingkat pengetahuannya. Beberapa jawaban dikatakan berbeda apabila jawaban tampak berlainan dan tidak mengikuti pola tertentu.

Dalam penelitian ini, untuk menilai kemampuan berpikir kreatif matematis siswa digunakan "The Torrance Tests of Creative Thinking (TTCT)". Kefasihan dalam penelitian mengacu pada kemampuan siswa dalam membuat gambar bangun datar yang beragam dan memiliki luas yang sama dengan luas bangun datar yang disajikan. Fleksibilitas mengacu pada kemampuan siswa menggunakan berbagai cara untuk mendapatkan luas yang sama dengan bangun datar yang disajikan. Kebaruan mengacu pada kemampuan siswa membuat bangun datar lain yang berbeda atau unik yang memiliki luas sama dengan bangun datar yang disajikan.

Gagasan tentang tingkat kemampuan berpikir kreatif matematis mempunyai banyak versi. Beberapa peneliti yang melakukan penelitian terkait Tingkat Berpikir Kreatif Matematis (TBKM) adalah Krulik \& Rudnik, De Bono dan Gotoh. Krulik Rudnick menyebutkan bahwa penalaran merupakan bagian dari berpikir yang tingkatnya di atas pengingatan (recall). Dalam penalaran dikategorikan dalam berpikir dasar (basic), berpikir kritis (criticall), dan berpikir kreatif (creative). De Bono mendefinisikan 4 tingkatan pencapaian dari perkembangan ketrampilan berpikir kreatif yang meliputi kesadaran berpikir, observasi berpikir, strategi berpikir dan refleksi berpikir. Sedangkan Gotoh menyatakan tingkat berpikir kreatif matematis terdiri dari 3 tingkatan yang dinamakan aktivitas ritmik (informal), algoritmis (formal) dan kontruktif (kreatif) (Siswono, 2008).

Penelitian ini menggunakan penjenjangan level tingkat berpikir kreatif matematis hasil penelitian yang dilakukan oleh Siswono. Siswono (2008) mengklasifikasikan tingkat kemampuan berpikir kreatif matematis siswa yang terdiri dari lima tingkat yaitu, TBKM 4 (Sangat Kreatif), TBKM 3 (Kreatif), TBKM 2 (Cukup Kreatif), TBKM 1 (Kurang Kreatif), dan TBKM 0 (Tidak Kreatif).

Keterangan lebih lengkapnya untuk level Tingkat Berpikir Kreatif Matematis (TBKM) hasil penelitian Siswono (2008) dapat dilihat pada Tabel 1 berikut. 
Tabel 1 Tingkat kemampuan berpikir kreatif matematis

\begin{tabular}{|c|c|}
\hline Level TKBM & Keterangan \\
\hline $\begin{array}{l}\text { Level } 4 \\
\text { (Sangat Kreatif) }\end{array}$ & $\begin{array}{l}\text { Siswa mampu menyelesaikan suatu masalah dengan lebih dari satu alternatif jawaban } \\
\text { maupun cara penyelesaian yang berbeda ("baru") dengan lancar (fasih) dan fleksibel atau } \\
\text { siswa hanya mampu mendapat satu jawaban yang "baru (tidak biasa dibuat siswa pada } \\
\text { tingkat berpikir umumnya)" tetapi dapat menyelesaikan dengan berbagai cara (fleksibel). } \\
\text { Siswa cenderung mengatakan bahwa mencari cara yang lain lebih sulit daripada mencari } \\
\text { jawaban yang lain. }\end{array}$ \\
\hline $\begin{array}{l}\text { Level } 3 \\
\text { (Kreatif) }\end{array}$ & $\begin{array}{l}\text { Siswa mampu membuat suatu jawaban yang "baru" dengan fasih, tetapi tidak dapat } \\
\text { menyusun cara berbeda (fleksibel) untuk mendapatkannya atau siswa dapat menyusun cara } \\
\text { yang berbeda (fleksibel) untuk mendapatkan jawaban yang beragam, meskipun jawaban } \\
\text { tersebut tidak "baru". Selain itu, siswa dapat membuat masalah yang berbeda ("baru") } \\
\text { dengan lancar (fasih) meskipun cara penyelesaian masalah itu tunggal atau dapat membuat } \\
\text { masalah yang beragam dengan cara penyelesaian yang berbeda-beda, meskipun masalah } \\
\text { tersebut tidak "baru". }\end{array}$ \\
\hline $\begin{array}{l}\text { Level } 2 \\
\text { (Cukup Kreatif) }\end{array}$ & $\begin{array}{l}\text { Siswa mampu membuat satu jawaban atau membuat masalah yang berbeda dari kebiasaan } \\
\text { umum ("baru") meskipun tidak dengan fleksibel ataupun fasih, atau siswa mampu } \\
\text { menyusun berbagai cara penyelesaian yang berbeda meskipun tidak fasih dalam menjawab } \\
\text { maupun membuat masalah dan jawaban yang dihasilkan tidak "baru". }\end{array}$ \\
\hline $\begin{array}{l}\text { Level } 1 \\
\text { (Kurang } \\
\text { Kreatif) }\end{array}$ & $\begin{array}{l}\text { Siswa mampu menjawab atau membuat masalah yang beragam (fasih), tetapi tidak mampu } \\
\text { membuat jawaban atau membuat masalah yang berbeda (baru), dan tidak dapat } \\
\text { menyelesaikan masalah dengan cara berbeda-beda (fleksibel). }\end{array}$ \\
\hline $\begin{array}{l}\text { Level } 0 \\
\text { (Tidak Kreatif) }\end{array}$ & $\begin{array}{l}\text { Siswa tidak mampu membuat alternatif jawaban maupun cara penyelesaian atau membuat } \\
\text { masalah yang berbeda dengan lancar (fasih) dan fleksibel. Kesalahan penyelesaian suatu } \\
\text { masalah disebabkan karena konsep yang terkait dengan masalah tersebut (dalam hal ini } \\
\text { rumus luas atau keliling) tidak dipahami atau diingat dengan benar. }\end{array}$ \\
\hline
\end{tabular}

Berdasarkan uraian di atas maka peneliti ingin mengetahui kemampuan berpikir kreatif matematis siswa kelas VI SD Negeri 40 Ambon pada materi bangun datar.

\section{Metode Penelitian}

Jenis penelitian ini adalah penelitian deskriptif dengan pendekatan kualitatif. Penelitian ini mendeskripsikan kemampuan berpikir kreatif matematis siswa dalam menyelesaikan tes kemampuan berpikir kreatif matematis siswa kelas VI SD Negeri 40 Ambon pada materi bangun datar. Pengambilan subjek dalam penelitian ini menggunakan teknik purposive sampling. Arikunto (2010) menyebutkan bahwa purposive sampling adalah menentukan sampel dengan pertimbangan tertentu yang dipandang dapat memberikan data secara maksimal. Dalam penelitian ini, peneliti menetapkan 5 orang siswa sebagai subjek penelitian. Pemilihan kelima orang siswa tersebut berdasarkan kriteria sebagai berikut:
1) Mampu membuat minimal 3 gambar bangun datar yang beragam dan memiliki luas yang sama dengan luas bangun datar yang diberikan.

2) Meminta pertimbangan guru untuk menentukan siswa yang sanggup untuk bekerja sama dengan peneliti saat melaksanakan penelitian.

3) Penelitian ini menggunakan teknik triangulasi dalam pengumpulan data, yaitu dengan tes kemampuan berpikir kreatif dan wawancara baku terbuka. Instrumen utama dalam penelitian ini yaitu peneliti sendiri karena peneliti sebagai pengumpul data dan menginterpretasi data yang diperoleh selama proses penelitian. Selain instrumen utama tersebut, instrumen pendukung dalam penelitian ini adalah Tes Berpikir Kreatif Matematis dan pedoman wawancara. Instrumen tes yang digunakan dibuat dengan mengacu pada indikator yang diadaptasi dari indikator kemampuan berpikir kreatif menurut Silver (Mulyaningsih dan Ratu, 2018) dan Siswono (2008) pada Tabel 2 berikut 


\begin{tabular}{|c|c|c|c|}
\hline Aspek & $\begin{array}{c}\text { Silver } \\
\text { (Mulyaningsih dan Ratu, } \\
\text { 2018) }\end{array}$ & $\begin{array}{c}\text { Siswono } \\
(2008)\end{array}$ & Peneliti \\
\hline Kefasihan & $\begin{array}{l}\text { Siswa menyelesaikan masalah } \\
\text { dengan bermacam-macam } \\
\text { interpretasi, } \\
\text { penyelesaian atau jawaban } \\
\text { masalah. }\end{array}$ & $\begin{array}{lr}\text { Kemampuan siswa meme- } \\
\text { cahkan atau menyelesai-kan } \\
\text { masalah dengan berbagai cara } \\
\text { yang bera-gam. Beberapa } \\
\text { jawaban dikatakan beragam jika } \\
\text { jawaban-jawaban r yang } \\
\text { diberikan siswa tampak } \\
\text { berlainan dan mengikuti pola } \\
\text { tertentu }\end{array}$ & $\begin{array}{l}\text { Siswa mampu membuat } \\
\text { gambar bangun datar } \\
\text { yang beragam dan } \\
\text { memiliki luas yang sama } \\
\text { dengan luas bangun datar } \\
\text { yang disajikan. }\end{array}$ \\
\hline Fleksibilitas & $\begin{array}{l}\text { - Siswa meme-cahkan } \\
\text { masalah dalam satu cara, } \\
\text { kemudian dengan } \\
\text { menggunakan cara lain. } \\
\text { - } \begin{array}{l}\text { Siswa mendiskusikan } \\
\text { berbagai metode } \\
\text { penyelesaian. }\end{array} \\
\end{array}$ & $\begin{array}{l}\text { Kemampuan siswa } \\
\text { menyelesaikan dengan memberi } \\
\text { jawaban yang berbeda. }\end{array}$ & $\begin{array}{lr}\text { Siswa } & \text { mampu } \\
\text { menggunakan } & \text { berbagai } \\
\text { cara untuk mendapatkan } \\
\text { luas yang } & \text { sama dengan } \\
\text { bangun datar } & \text { yang } \\
\text { disajikan. } & \end{array}$ \\
\hline Kebaruan & $\begin{array}{l}\text { Siswa memeriksa beberapa } \\
\text { metode penyelesaian atau } \\
\text { jawaban, kemudian membuat } \\
\text { lainnya yang berbeda. }\end{array}$ & $\begin{array}{l}\text { Kemampuan siswa men-jawab } \\
\text { atau menyelesaikan dengan } \\
\text { beberapa jawaban yang } \\
\text { berbeda-beda tetapi bernilai } \\
\text { benar atau satu jawaban yang } \\
\text { tidak biasa dilakukan oleh siswa } \\
\text { pada tingkat pengetahuannya. } \\
\text { Beberapa jawaban tersebut } \\
\text { dikatakan berbeda jika jawaban } \\
\text { tersebut tampak berlainan dan } \\
\text { tidak mengikuti pola tertentu }\end{array}$ & $\begin{array}{ll}\text { Siswa mampu membuat } \\
\text { bangun datar lain yang } \\
\text { berbeda atau unik yang } \\
\text { memiliki luas sama } \\
\text { dengan bangun datar } \\
\text { yang disajikan. }\end{array}$ \\
\hline
\end{tabular}

Penelitian ini menggunakan teknik analisis data Miles dan Huberman yaitu reduksi data, penyajian data dan penarikan kesimpulan (Mataheru, 2010). Analisis data dilakukan dengan menganalisis data hasil tes dan analisis data hasil wawancara. Analisis data hasil tes mulai dilakukan berdasarkan hasil tes siswa. Dari hasil tes siswa, Peneliti mengklasifikasikan siswa ke dalam 2 kelompok yaitu kelompok pertama (kelompok siswa yang bisa membuat minimal 3 gambar bangun datar yang beragam dan memiliki luas yang sama dengan luas bangun datar yang diberikan) dan kelompok kedua (kelompok siswa yang tidak bisa membuat minimal 3 gambar bangun datar yang beragam dan memiliki luas yang sama dengan luas bangun datar yang diberikan). Selanjutnya Peneliti menganalisis hasil kerja siswa yang masuk pada kelompok pertama. Analisis dilakukan pada jawaban dan langkahlangkah penyelesaian yang digunakan tiap subjek. Analisis dilakukan dengan memperhatikan indikator kemampuan berpikir kreatif matematis seperti yang tertera pada Tabel 2. Selanjutnya Peneliti berdiskusi dengan guru kelas 6 untuk menentukan subjek penelitian dari kelompok pertama (kelompok siswa yang bisa membuat minimal 3 gambar bangun datar yang beragam dan memiliki luas yang sama dengan luas bangun datar yang diberikan).

Setelah menganalisis hasil tes, dilakukan wawancara terhadap 5 subjek terpilih yang mewakili masing-masing tingkat. Keabsahan data dalam penelitian ini dijamin dengan menggunakan triangulasi metode. Teknik ini dilakukan dengan cara membandingkan hasil wawancara dengan hasil tes yang dikerjakan. Wawancara dilakukan dengan pertanyaan yang sama tetapi dengan instruksi yang lebih mendetail bagi subjek untuk menjawab. Wawancara dilakukan tujuannya untuk mengetahui alasan subjek dalam menyelesaikan soal tes. Hasil wawancara berupa data kualitatif yang sudah diperiksa keabsahannya kemudian dianilisis dengan langkah-langkah sesuai dengan teknik analisis Miles dan Huberman. Pertama, mereduksi data yaitu dalam hal ini yang dimaksud adalah kegiatan yang mengacu pada proses pemilihan, pemusatan perhatian, penyederhanaan, pengabstraksian, dan tranfonformasi data mentah yang diperoleh dari lapangan tentang tingkat kemampuan berpikir kreatif siswa dalam menyelesaikan soal yang diberikan kepada subyek. Kedua, penyajian data yaitu meliputi 
pengumpulan data yang terorganisasi dan terkategori dituliskan kembali, sehingga memungkinkan untuk menarik kesimpulan dari data tersebut. Penyajian data yang dilakukan dalam penelitian ini adalah pengklasifikasian dan mendeskripsikan berdasarkan tiga indikator berpikir kreatif yaitu kefasihan, fleksibilitas dan kebaruan. Selanjutnya siswa dikategorikan pada tingkat kemampuan berpikir kreatif yang terdiri dari lima tingkat, yaitu Level 4 (sangat kreatif), Level 3 (kreatif), Level 2 (cukup kreatif), Level 1 (kurang kreatif), dan Level 0 (tidak kreatif). Terakhir menarik kesimpulan untuk mengetahui kemampuan berpikir kreatif matematis siswa kelas VI SD Negeri 40 Ambon pada materi bangun datar.

\section{Hasil dan Pembahasan}

a. Subjek $\mathrm{S}_{1}$ memiliki Tingkat Kemampuan Berpikir Kreatif 4

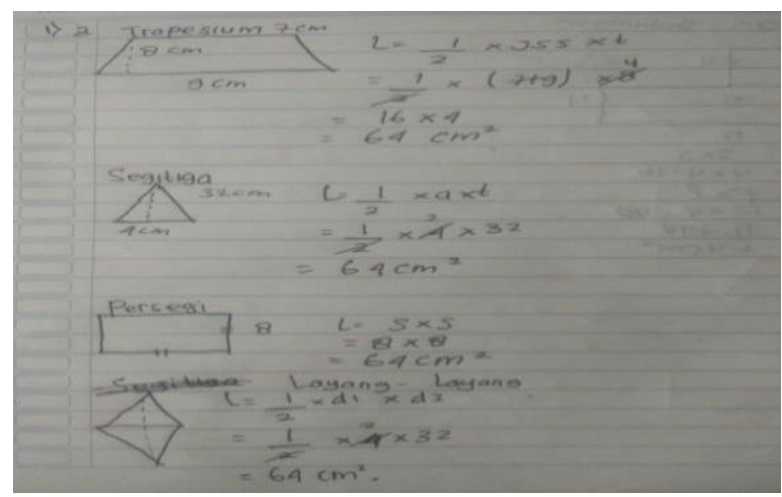

Gambar 1. Jawaban tertulis indikator kefasihan $S_{1}$

Dari Gambar 1, $\mathrm{S}_{1}$ mampu memberikan 4 bangun datar yang berbeda beserta ukurannya, di mana bangun-bangun tersebut memiliki luas yang sama besar dengan luas yang diketahui pada soal. Menurut Silver (Mulyaningsih dan Ratu, 2018), kefasihan yaitu siswa menyelesaikan masalah dengan bermacam-macam interpretasi, metode penyelesaian atau jawaban masalah. Hal ini diperkuat dengan pernyataan Siswono (2008) bahwa kefasihan yaitu kemampuan siswa memecahkan atau menyelesaikan masalah dengan berbagai cara yang beragam. Oleh karena itu $S_{1}$ memenuhi indikator kefasihan karena subjek tidak hanya memberikan satu atau dua bangun saja tetapi dengan fasih $S_{1}$ mampu memberikan beberapa bangun yang dia buat dengan luas yang sama seperti yang diketahui pada soal.

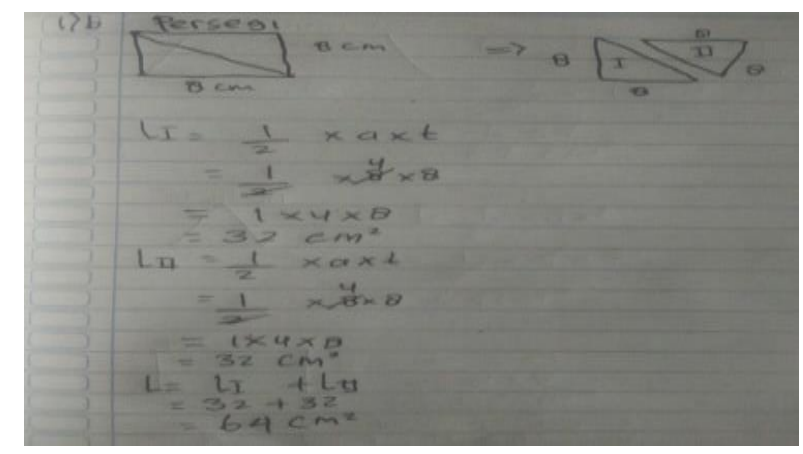

Gambar 2. Jawaban tertulis indikator fleksibilitas $S_{1}$

$\mathrm{S}_{1}$ mampu memberikan jawaban yang berbeda untuk mencari suatu luas bangun yang telah dia buat sebelumnya, seperti terlihat pada Gambar 2. $S_{1}$ mampu mencari luas dari persegi yang dia buat bukan dengan rumus luas pada umumnya melainkan $S_{1}$ mampu menemukan luas dari persegi tersebut dari luas segitiga yang dia dapat setelah membagi persegi tersebut secara diagonal, yang kemudian luas kedua segitiga tersebut dijumlahkan untuk menemukan luas persegi. Silver (Mulyaningsih dan Ratu, 2018) menyatakan bahwa fleksibilitas yaitu siswa memecahkan masalah dalam satu cara, kemudian dengan menggunakan cara lain dan mendiskusikan berbagai metode penyelesaian. Hal ini diperkuat dengan pernyataan Siswono (2008) bahwa fleksibilitas adalah kemampuan siswa memecahkan masalah dengan berbagai cara yang berbeda. Oleh karena itu berdasarkan indikator kemampuan berpikir kreatif matematis, $\mathrm{S}_{1}$ memenuhi aspek fleksibilitas.

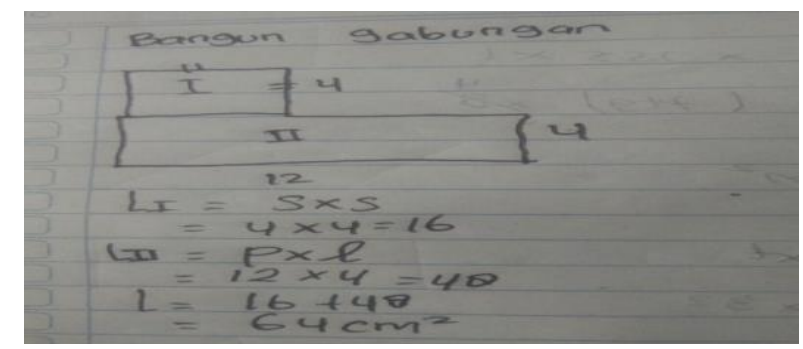

Gambar 3. Jawaban tertulis indikator kebaruan $S_{1}$

$\mathrm{S}_{1}$ juga mampu memberikan sesuatu yang baru dari jawabannya. Sebagaimana yang terlihat pada Gambar 3, $S_{1}$ mampu membuat bangun gabungan di mana bangun gabungan ini merupakan bangun datar lain yang berbeda atau yang unik dari empat bangun datar yang disajikan $\mathrm{S}_{1}$ pada hasil kerjanya. Silver (Mulyaningsih dan Ratu, 2018) menyatakan bahwa kebaruan adalah siswa memeriksa beberapa metode penyelesaian atau jawaban, kemudian membuat lainnya yang berbeda. Pernyataan ini diperkuat dengan pernyataan Siswono (2008) bahwa kebaruan adalah kemampuan siswa menjawab atau 
menyelesaikan dengan beberapa jawaban yang berbeda-beda tetapi bernilai benar atau satu jawaban yang tidak biasa dilakukan oleh siswa pada tingkat pengetahuannya. Oleh karena itu berdasarkan indikator kemampuan berpikir kreatif matematis, $S_{1}$ memenuhi indikator kebaruan karena $S_{1}$ dengan mampu memberikan jawaban yang baru dan berbeda dari pada umumnya.

Siswa dikategorikan masuk pada level 4 (sangat kreatif) jika siswa mampu menyelesaikan suatu masalah dengan lebih dari satu alternatif jawaban maupun cara penyelesaian yang berbeda ("baru") dengan lancar (fasih) dan fleksibel atau siswa hanya mampu mendapat satu jawaban yang "baru (tidak biasa dibuat siswa pada tingkat berpikir umumnya)" tetapi dapat menyelesaikan dengan berbagai cara (fleksibel). Siswa cenderung mengatakan bahwa mencari cara yang lain lebih sulit daripada mencari jawaban yang lain (Siswono, 2008). Berdasarkan level Tingkat Berpikir Kreatif Matematis (TBKM) hasil penelitian Siswono (2008) ini, maka $S_{1}$ masuk pada level 4 (sangat kreatif) karena $S_{1}$ mampu memberikan 4 bangun datar yang berbeda beserta ukurannya dengan fasih, menunjukkan cara lain dalam menemukan luas persegi, dan $S_{1}$ juga mampu memberikan sesuatu yang baru dari jawabannya dengan membuat bangun gabungan di mana bangun gabungan ini merupakan bangun datar lain yang berbeda atau yang unik dari empat bangun datar yang disajikan $S_{1}$ pada hasil kerjanya.

\section{b. Subjek $\mathrm{S}_{2}$ memiliki Tingkat} KemampuanBerpikir Kreatif 3

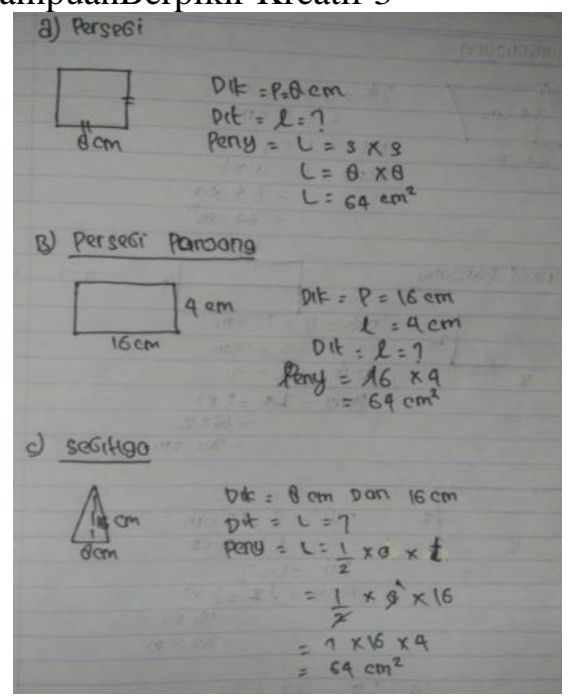

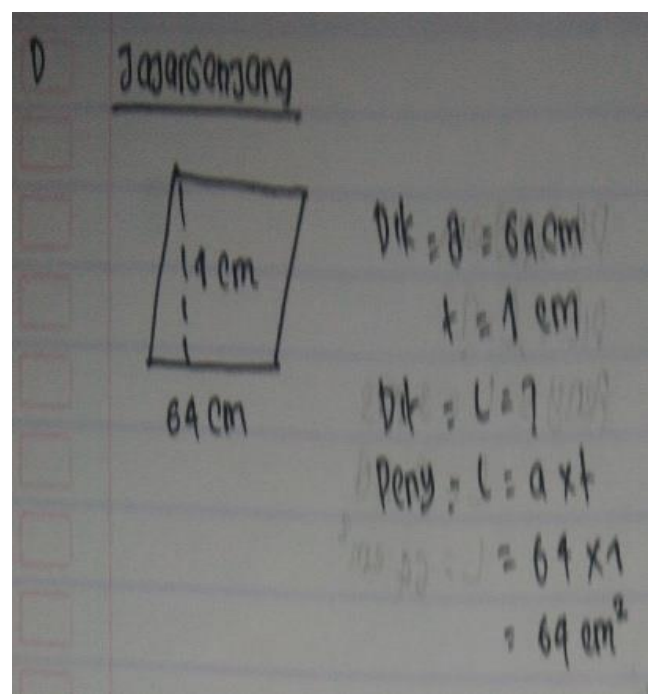

Gambar 4. Jawaban tertulis indikator kefasihan $\mathrm{S}_{2}$

Terlihat pada Gambar 4, $\mathrm{S}_{2}$ mampu memberikan jawaban yang lengkap dimana $S_{2}$ memberikan 4 bangun datar dengan berbagai ukuran yang berbeda berbeda-beda dan bernilai benar yang mempunyai luas yang sama berdasarkan pada luas bangun yang diketahui pada soal. Dikatakan bernilai benar karena jika ukuran-ukuran yang diberikan pada gambar itu disubtitusikan ke dalam rumus luas bangun datar yang di gambar $S_{2}$, maka ukuran luasnya sama dengan ukuran luas yang di minta pada soal. Menurut Silver (Mulyaningsih dan Ratu, 2018), kefasihan yaitu siswa menyelesaikan masalah dengan bermacam-macam interpretasi, metode penyelesaian atau jawaban masalah. Hal ini diperkuat dengan pernyataan Siswono (2008) bahwa kefasihan yaitu kemampuan siswa memecahkan atau menyelesaikan masalah dengan berbagai cara yang beragam. Oleh karena itu $\mathrm{S}_{2}$ memenuhi indikator kefasihan karena $S_{2}$ mampu menggambar beberapa bangun datar yang berbeda dan memiliki luas yang sama dengan luas yang diketahui pada soal.

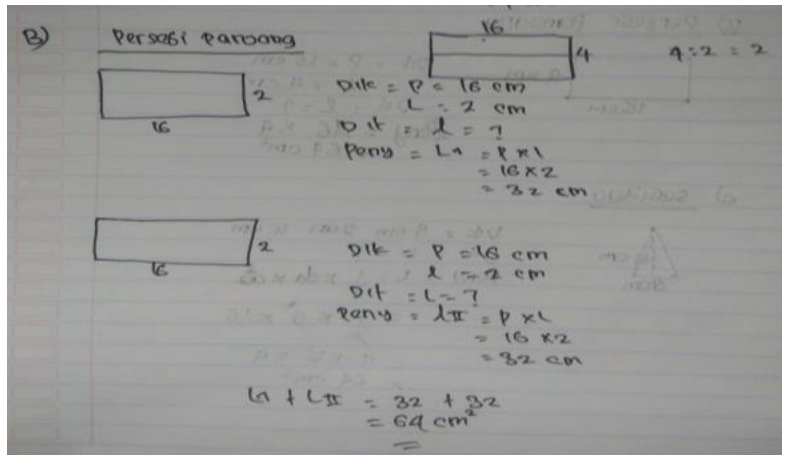

Gambar 5. Jawaban tertulis indikator fleksibilitas $S_{2}$ 
$\mathrm{S}_{2}$ mampu memberikan jawaban yang berbeda untuk mencari suatu luas bangun yang telah dia buat sebelumnya. Hal ini terlihat pada Gambar 5, dimana $S_{2}$ mampu menunjukkan bahwa subjek tidak hanya mampu memberikan satu cara dalam menemukan luas persegi panjang, namun subjek mampu menemukan cara lain yaitu dengan membagi persegi panjang yang diketahui tersebut secara horizontal, sehingga terbentuk dua buah persegi panjang dengan ukuran lebar yang berbeda dengan ukuran lebar persegi panjang yang telah di buat $S_{2}$ pada bagian a. Silver (Mulyaningsih dan Ratu, 2018) menyatakan bahwa fleksibiltas yaitu siswa memecahkan masalah dalam satu cara, kemudian dengan menggunakan cara lain dan mendiskusikan berbagai metode penyelesaian. Hal ini diperkuat dengan pernyataan Siswono (2008) bahwa fleksibilitas adalah kemampuan siswa memecahkan masalah dengan berbagai cara yang berbeda. Oleh karena itu berdasarkan indikator kemampuan berpikir kreatif matematis $\mathrm{S}_{1}$ memenuhi aspek fleksibilitas.

Namun dari hasil kerja $S_{2}$, belum ada satu bangun yang unik atau berbeda yang memiliki luas yang sama dengan luas pada soal. Hal ini menunjukkan bahwa $\mathrm{S}_{2}$ belum mampu memunculkan indikator kebaruan.

Siswa dikategorikan masuk pada level 3 (kreatif) jika siswa mampu membuat suatu jawaban yang "baru" dengan fasih, tetapi tidak dapat menyusun cara berbeda (fleksibel) untuk mendapatkannya atau siswa dapat menyusun cara yang berbeda (fleksibel) untuk mendapatkan jawaban yang beragam, meskipun jawaban tersebut tidak "baru". Selain itu, siswa dapat membuat masalah yang berbeda ("baru") dengan lancar (fasih) meskipun cara penyelesaian masalah itu tunggal atau dapat membuat masalah yang beragam dengan cara penyelesaian yang berbeda-beda, meskipun masalah tersebut tidak "baru" (Siswono, 2008). Berdasarkan level Tingkat Berpikir Kreatif Matematis (TBKM) hasil penelitian Siswono (2008) ini, maka $S_{2}$ masuk pada level 3 (kreatif) karena $S_{2}$ fasih dalam memberikan 4 bangun datar yang berbeda beserta ukurannya dengan tepat dan $\mathrm{S}_{2}$ mampu menunjukkan cara lain dalam menemukan luas persegi panjang, walaupun $S_{2}$ belum mampu memberikan sesuatu yang berbeda atau baru pada bangun-bangun datar yang telah dibuatnya.

c. Subjek $\mathrm{S}_{3}$ memiliki Tingkat Kemampuan
Berpikir Kreatif 2
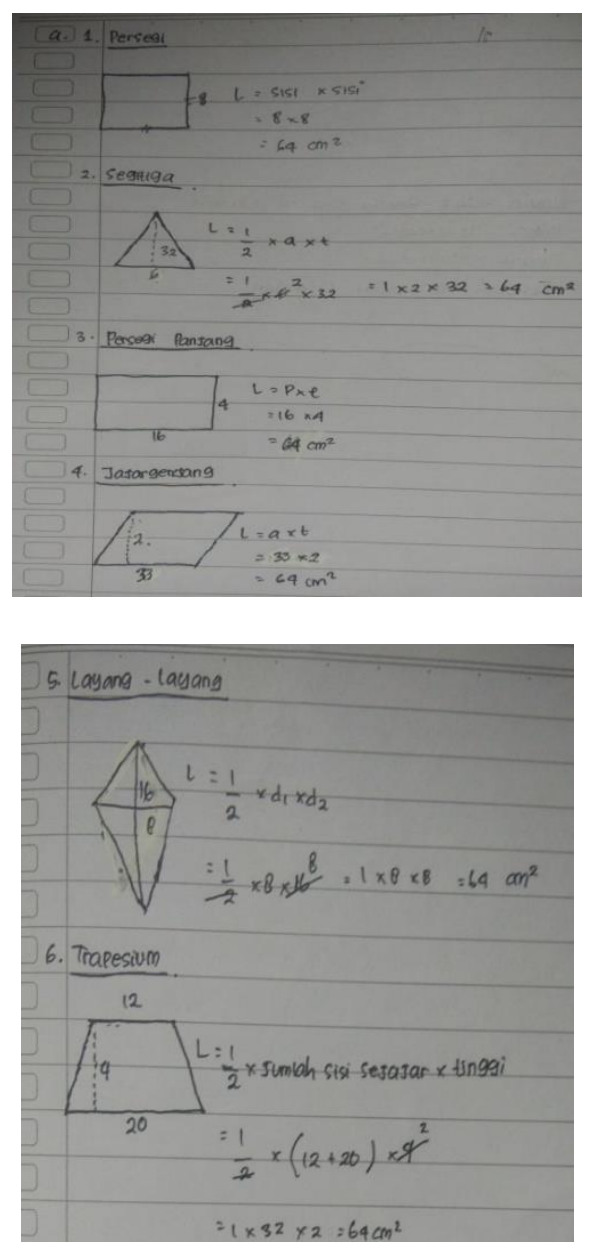

Gambar 6. Jawaban tertulis $S_{3}$ Pada Nomor 1a

Menurut Silver (Mulyaningsih dan Ratu, 2018), kefasihan yaitu siswa menyelesaikan masalah dengan bermacam-macam interpretasi, metode penyelesaian atau jawaban masalah. Hal ini diperkuat dengan pernyataan Siswono (2008) bahwa kefasihan yaitu kemampuan siswa memecahkan atau menyelesaikan masalah dengan berbagai cara yang beragam. $\mathrm{S}_{3}$ mampu memberikan 6 bangun datar tetapi beberapa jawaban yang diberikan masih belum tepat. Beberapa jawaban yang belum tepat yang diberikan oleh $\mathrm{S}_{3}$ terlihat pada bangun kedua (segitiga) dan bangun keempat (jajargenjang). Berdasarkan pada dua kesalahan yang dibuat oleh $\mathrm{S}_{3}$, maka subjek $\mathrm{S}_{3}$ belum mampu memberikan bermacam-macam jawaban sehingga indikator kefasihan belum mampu dimunculkan.

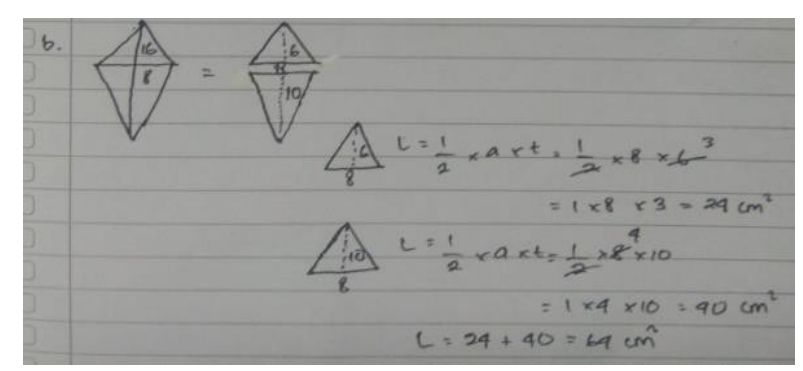

Gambar 7. Jawaban tertulis indikator fleksibilitas $S_{3}$ 
$\mathrm{S}_{3}$ mampu menunjukkan cara lain untuk menentukan luas layang-layang, yaitu dengan membagi layang-layang menjadi dua buah segitiga, dimana selanjutnya luas kedua buah segitiga tersebut dijumlahkan untuk memperoleh luas layang-layang. Silver (Mulyaningsih dan Ratu, 2018) menyatakan bahwa fleksibiltas yaitu siswa memecahkan masalah dalam satu cara, kemudian dengan menggunakan cara lain dan mendiskusikan berbagai metode penyelesaian. Hal ini diperkuat dengan pernyataan Siswono (2008) bahwa fleksibilitas adalah kemampuan siswa memecahkan masalah dengan berbagai cara yang berbeda. Oleh karena itu berdasarkan indikator kemampuan berpikir kreatif matematis, $S_{3}$ memenuhi aspek fleksibilitas.

Pada dari hasil kerja $S_{3}$, belum ada satu bangun yang unik atau berbeda yang memiliki luas yang sama dengan luas pada soal. Hal ini menunjukkan bahwa $\mathrm{S}_{3}$ belum mampu memunculkan indikator kebaruan.

Siswa dikategorikan masuk pada level 2 (cukup kreatif) jika siswa mampu membuat satu jawaban atau membuat masalah yang berbeda dari kebiasaan umum ("baru") meskipun tidak dengan fleksibel ataupun fasih, atau siswa mampu menyusun berbagai cara penyelesaian yang berbeda meskipun tidak fasih dalam menjawab maupun membuat masalah dan jawaban yang dihasilkan tidak "baru" (Siswono, 2008). Berdasarkan level Tingkat Berpikir Kreatif Matematis (TBKM) hasil penelitian Siswono (2008) ini, maka $S_{3}$ masuk pada level 2 (cukup kreatif) karena $S_{3}$ mampu menunjukkan cara lain dalam menemukan luas layang-layang, walaupun $\mathrm{S}_{3}$ tidak fasih dalam memberikan 6 bangun datar yang berbeda beserta ukurannya dengan tepat dan $\mathrm{S}_{3}$ juga belum mampu memberikan sesuatu yang berbeda atau baru pada bangun-bangun datar yang telah dibuatnya.

d. Subjek $\mathrm{S}_{4}$ memiliki Tingkat Kemampuan Berpikir Kreatif 1

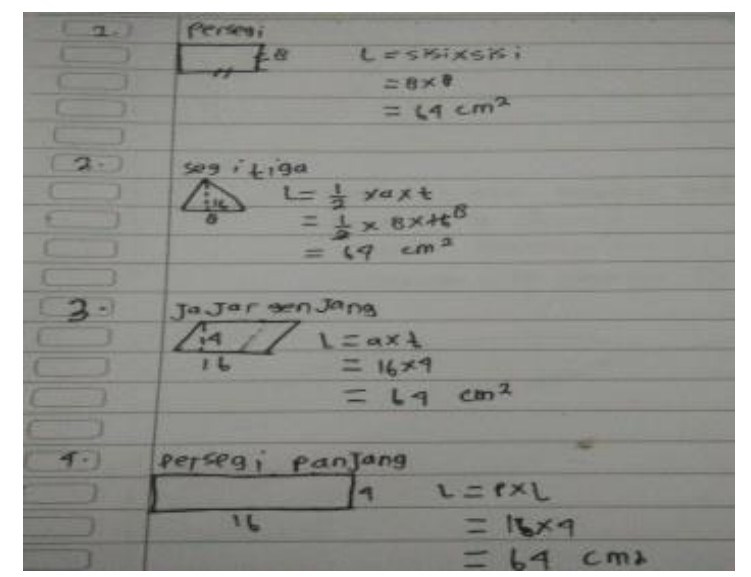

Gambar 8. Jawaban tertulis indikator kefasihan $\mathrm{S}_{4}$
$\mathrm{S}_{4}$ mampu memberikan 4 bangun datar yang berbeda lengkap dengan ukuran dan luas yang sesuai dengan yang ditanyakan. Menurut Silver (Mulyaningsih dan Ratu, 2018), kefasihan yaitu siswa menyelesaikan masalah dengan bermacammacam interpretasi, metode penyelesaian atau jawaban masalah. Hal ini diperkuat dengan pernyataan Siswono (2008) bahwa kefasihan yaitu kemampuan siswa memecahkan atau menyelesaikan masalah dengan berbagai cara yang beragam. Oleh karena itu $\mathrm{S}_{4}$ memenuhi indikator kefasihan karena subjek mampu memberikan variasi jawaban bangun yaitu dengan berbagai macam bangun datar yang subjek buat yang mempunyai luas yang sama seperti yang diketahui pada soal.

Kefasihan yang ditunjukkan dengan baik oleh $\mathrm{S}_{4}$ tidak diikuti oleh dua indikator lainnya yaitu fleksibilitas dan kebaruan. $\mathrm{S}_{4}$ mengalami kesulitan dalam memberikan alternatif jawaban untuk menemukan luas dari salah satu bangun yang telah dibuatnya pada bagian a. Oleh karena itu berdasarkan indikator kemampuan berpikir kreatif matematis, $\mathrm{S}_{4}$ belum memiliki fleksibilitas dalam dirinya. Sama halnya dengan indikator fleksibilitas, $\mathrm{S}_{4}$ juga belum mampu memberikan bangun datar lain yang berbeda atau unik. Oleh karena itu berdasarkan indikator kemampuan berpikir kreatif matematis, $S_{4}$ belum menunjukkan indikator kebaruan karena $\mathrm{S}_{4}$ belum mampu memberikan bangun datar yang baru dan berbeda dari pada umumnya.

Siswa dikategorikan masuk pada level 1 (kurang kreatif) jika siswa mampu menjawab atau membuat masalah yang beragam (fasih), tetapi tidak mampu membuat jawaban atau membuat masalah yang berbeda (baru), dan tidak dapat menyelesaikan masalah dengan cara berbeda-beda (fleksibel). Berdasarkan level Tingkat Berpikir Kreatif Matematis (TBKM) hasil penelitian Siswono (2008) ini, maka $\mathrm{S}_{4}$ masuk pada level 1 (kurang kreatif) karena $\mathrm{S}_{4}$ fasih dalam memberikan 4 bangun datar yang berbeda beserta ukurannya dengan tepat, namun $\mathrm{S}_{4}$ belum mampu menunjukkan cara lain dalam menemukan luas bangun datar yang dibuatnya pada bagian a, dan $\mathrm{S}_{4}$ juga belum mampu menunjukkan sesuatu yang berbeda atau baru pada bangun-bangun datar yang telah dibuatnya. 
e. Subjek $\mathrm{S}_{5}$ memiliki Tingkat Kemampuan Berpikir Kreatif 0

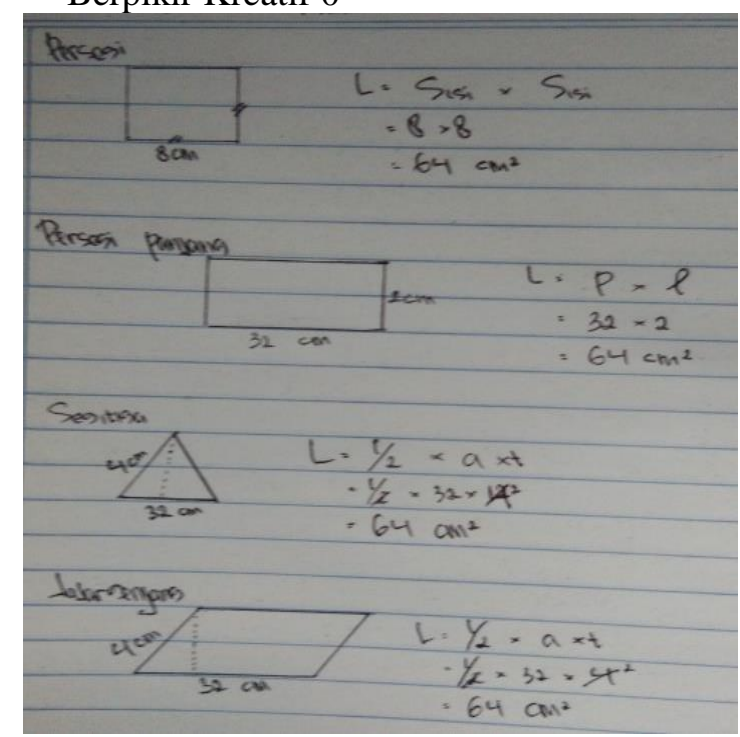

Gambar 6. Jawaban tertulis $\mathrm{S}_{5}$

Menurut Silver (Mulyaningsih dan Ratu, 2018), kefasihan yaitu siswa menyelesaikan masalah dengan bermacam-macam interpretasi, metode penyelesaian atau jawaban masalah. Hal ini diperkuat dengan pernyataan Siswono (2008) bahwa kefasihan yaitu kemampuan siswa memecahkan atau menyelesaikan masalah dengan berbagai cara yang beragam. $\mathrm{S}_{5}$ mampu memberikan 4 bangun datar beserta ukurannya, hanya saja ukuran pada bangun segitiga kurang tepat. Selain itu, ukuran tinggi jajargenjang dituliskan pada sisi miringnya. Begitu juga ukuran tinggi pada segitiga dituliskan pada sisi miringnya. Berdasarkan pada kesalahan-kesalahan yang dibuat oleh $S_{5}$, maka $S_{5}$ belum mampu memberikan bermacam-macam jawaban sehingga indikator kefasihan belum mampu dimunculkan oleh $\mathrm{S}_{5}$.

$\mathrm{S}_{5}$ juga belum mampu menunjukkan indikator lainnya yaitu fleksibilitas dan kebaruan. $\mathrm{S}_{5}$ mengalami kesulitan dalam memberikan alternatif jawaban untuk menemukan luas dari salah satu bangun yang telah dibuatnya pada bagian a. Oleh karena itu berdasarkan indikator kemampuan berpikir kreatif matematis, $\mathrm{S}_{4}$ belum memiliki fleksibilitas dalam dirinya. Sama halnya dengan indikator fleksibilitas, $S_{4}$ juga belum mampu memberikan bangun datar lain yang berbeda atau unik. Oleh karena itu berdasarkan indikator kemampuan berpikir kreatif matematis, $\mathrm{S}_{4}$ belum menunjukkan indikator kebaruan karena $\mathrm{S}_{4}$ belum mampu memberikan bangun datar yang baru dan berbeda dari pada umumnya.

Siswa dikategorikan masuk pada level 0 (tidak kreatif) jika siswa tidak mampu membuat alternatif jawaban maupun cara penyelesaian atau membuat masalah yang berbeda dengan lancar (fasih) dan fleksibel. Kesalahan penyelesaian suatu masalah disebabkan karena konsep yang terkait dengan masalah tersebut (dalam hal ini rumus luas atau keliling) tidak dipahami atau diingat dengan benar. Berdasarkan level Tingkat Berpikir Kreatif Matematis (TBKM) hasil penelitian Siswono (2008) ini, maka $\mathrm{S}_{5}$ masuk pada level 0 (tidak kreatif) karena $\mathrm{S}_{5}$ belum mampu memunculkan ketiga indikator dari kemampuan berpikir kreatif matematis.

\section{Kesimpulan}

Berdasarkan analisis dan pembahasan yang telah dilakukan dapat disimpulkan bahwa kelima subjek yang mewakili tiap tingkat kemampuan berpikir kreatif memiliki karakter yang berbeda-beda dalam memperlihatkan indikator kemampuan berpikir kreatif, sehingga solusi yang disarankan adalah 1). Guru hendaknya menanamkan konsep dasar materi bangun datar dalam kegiatan pembelajaran karena materi bangun datar akan diajarkan lagi pada jenjang selanjutnya. 2) Guru sebaiknya memberikan kesempatan kepada siswa untuk menggunakan cara sendiri dalam menyelesaikan soal-soal terkait bangun datar. 3) Perlu dilakukan penelitian yang lebih lanjut sebagai upaya untuk meningkatkan kemampuan berpikir kreatif siswa yang masih rendah berdasarkan hasil analisis pada penelitian ini.

\section{Daftar Pustaka}

Adjie, Nahrowi dan Maulana. 2006. Pemecahan Masalah Matematika. Bandung: UPI Press.

Amalia, Anissa; Sugiatno dan Dede Suratman. 2018. Proses Berpikir Kreatif Siswa dalam Menyelesaikan Masalah Bangun Ruang Berdasarkan Tahapan Wallas Di SMP. Jurnal Pendidikan dan Pembelajaran. Vol. 7, No 7.

Arikunto, Suharsimi. 2010. Prosedur Penelitian Suatu Pendekatan Praktik. Jakarta: Rineka Cipta.

Fardah, Kinanti Dini. 2012. Analisis Proses dan Kemampuan Berpikir Kreatif Siswa dalam Matematika Melalui Open-Ended. Jurnal KREANO diterbitkan oleh Jurusan Matematika FMIPA UNNES Volume 3 Nomor 2 Desember 2012.

Hamzah, Ali dan Muhlisrarini. 2014. Perencanaan dan Strategi Pembelajaran Matematika. Jakarta: PT Grafindo Persada.

Hendriana, Heris dan Utari Sumarno. 2014. Penilaian Pembelajaran Matematika. Bandung: PT Refika Aditama.

Hendriana, Heris; Euis Eti Rohaeti dan Utari Sumarno. 2018. Hard Skills dan Soft Skills Matematik Siswa. Bandung: PT Refika Aditama.

Khoiri, Miftahul. 2014. Pemahaman Siswa pada Konsep Segiempat Berdasarkan Teori Van 
Hiele. Prosiding Seminar Nasional Matematika, Universitas Jember, 19 November 2014.

Kuswana, Wowo Sunarya. 2011. Taksonomi Berpikir. Bandung : PT Remaja Rosdakarya.

La Moma. 2003. Strategi Kognitif dan Kesalahan Siswa Kelas VI SD Dalam Menyelesaikan Soal Pengukuran Panjang. Tesis Universitas Negeri Surabaya. Tidak diterbitkan.

Mahmudi, A. 2008. Mengembangkan Soal Terbuka (Open-Ended Problem) dalam Pembelajaran Matematika. Semnas Matematika dan Pendidikan Matematika. Yogyakarta: Universitas Negeri Yogyakarta.

Masykur, Abdul Halim Fathani. 2007. Mathematical Intelligence. Jogjakarta: PT.Ar-Ruzz Media.

Mataheru, Wilmintjie. 2010. Profil Proses Kognitif Siswa SD Dalam Pemecahan Masalah Matematika Yang Terkait Dengan Sifat-Sifat Operasi Hitung Bilangan Cacah. Disertasi. Universitas Surabaya.

Mulyaningsih, Tri dan Novisita Ratu. 2018. Analisis Kemampuan Berpikir Kreatif Siswa Smp Dalam Memecahkan Masalah Matematika Pada Materi Pola Barisan Bilangan. Jurnal Ilmiah Pendidikan Matematika Volume 3 Nomor 1

Munandar, Utami. 2012. Pengembangan Kreativitas Anak Berbakat. Jakarta:

PT. RinekaCipta.

Prastowo, Andi. 2011. Memahami Metode-metode Penelitian Suatu Tinjauan Teoritis \& Praktis. Jogjakarta: Ar-Ruz Media.

Ramadhani, Dini dan Nuryanis. 2017. Analisis Kemampuan Berpikir Kreatif Matematis Siswa SD Dalam Menyelesaikan Open-Ended Problem. Jurnal JPSD Voume 4 No. 1 Tahun 2017.

Ratumanan, Tanwey Gerson. 2015. Belajar \& Pembelajaran Serta Faktor-faktor yang Mempengaruhinya. Yogyakarta: Pensil Komunika. Edisi Ketiga.

Siswono, Tatag Yuli Eko. 2005. Menilai Kreativitas Siswa dalam Matematika. Surabaya: Unesa University Press.

Siswono, Tatag Yuli Eko. 2006. Desain Tugas untuk Mengidentifikasi Kemampuan Berpikir Kreatif Siswa dalam Matematika. Surabaya: Unesa University Press.

Siswono, Tatag Yuli Eko. 2008. Penjenjangan Kemampuan Berpikir Kreatif dan Identifikasi Tahap Berpikir Kreatif Siswa dalam Memecahkan dan Mengajukan Masalah Matematika. Surabaya: Unesa University Press.

Slameto. 2010. Belajar dan Faktor-faktor yang Mempengaruhinya. Jakarta: PT. Rineka Cipta.

Widiastuti, Yeni dan Ratu Ilma Indra Putri. 2018. Kemampuan Berpikir Kreatif Siswa Pada Pembelajaran Operasi Pecahan Menggunakan Pendekatan Open-Ended. Jurnal Pendidikan Matematika Volume 12, No. 2, Juli 2018.
Yusmanida, D. E. 2014. Pengaruh Gaya Belajar, Kreativitas Dan Kecerdasan Emosi Terhadap Kemandirian Belajar Siswa Kelas X SMK PIRI I Yogyakarta. Yogyakarta: Universitas Negeri Yogyakarta 